\title{
JOB SATISFACTION OF HOSPITAL NURSING STAFF
}

\author{
CHARLOTTE PIETERSEN \\ charlottep@ul.ac.za \\ Department of Human Resource Management \\ University of Limpopo
}

\begin{abstract}
Health care managers realize that job satisfaction impacts on nursing staff retention. This study examined the job satisfaction of nursing staff $(\mathrm{N}=109)$ at a government hospital. Just more than half of the respondents were generally satisfied. Feelings that nursing is worthwhile and satisfying, and financial stability at the hospital could promote staff retention. Specific intrinsic - (promotion), and extrinsic factors (routinization, working conditions, pay, interaction with supervisors, and organizational support) could impact negatively on retention. Management should use these findings as a basis for staff consultation, developmental strategies, and interventions. Future research on other nursing populations is recommended.
\end{abstract}

\section{OPSOMMING}

Gesondheidsorgbestuurders besef dat werkstevredenheid die retensie van verpleegpersoneel beïnvloed. Die werkstevredenheid van die verpleegpersoneel $(\mathrm{N}=109)$ in ' $\mathrm{n}$ staatshospitaal is in hierdie studie ondersoek. Net minder as die helfte van die respondente was in die algemeen tevrede. Personeel retensie kan deur gevoelens dat verpleging waardevol en betekenisvol is, en finansiële stabiliteit in die organisasie, bevorder word. Spesifieke intrinsieke (bevordering) en ekstrinsieke werksfaktore (geroetineerde werk, werkstoestande, betaling, interaksie met toesighouers, and organisasie ondersteuning) kan retensie negatief bë̈nvloed. Bestuur kan die bevindings as ' $n$ basis vir personeel konsultasie, ontwikkelingstrategieë en intervensies gebruik. Verdere navorsing op ander verpleegpopulasies word aanbeveel.

Critical nursing staff shortages are a worldwide phenomenon, and filling vacant positions is becoming more and more difficult (Miracle \& Miracle, 2004; Moyle, Skinner, Rowe \& Gork, 2003). Hospitals in South Africa also experience critical nursing staff shortages. Venter (2003) pointed out that these critical shortages are developing at a time when there is an escalation in communicable diseases, such as HIV/AIDS. He compared nurse/population ratios in the different provinces in South Africa, released by Statistics SA in 2002, to the World Health Organisation's minimum nurse/population ratio of 200 per 100000. These statistics showed, for instance, that Limpopo, Mpumalanga, the Northern Cape, and the Eastern Cape reflected ratios well below the national average of 343 per 100000

Reducing the turnover rate among nursing staff remains one of the most effective ways to decrease staff shortages (Evans, 2005; Lacey, 2003). Today, health care managers acknowledge the link between retention and job satisfaction (Murrow \& Nowak, 2005). According to Igbaria, Meredith and Smith (1994), job satisfaction is the most important factor in determining a person's intention to stay with an organization. A logical starting point for any development and/or intervention program aimed at maintaining and/or enhancing the satisfaction of employees is to obtain input from employees on their job satisfaction (Gunner-Vaughn, 2003).

The hospital administrators at a government hospital situated in the Capricorn District of the Limpopo Province (South Africa) also keenly appreciate that employee job satisfaction impacts on nursing staff retention. They expressed a need to obtain baseline data on the job satisfaction of nursing staff at the hospital. This information will be used for staff discussions, developmental strategies, and intervention activities to maintain and/or enhance the job satisfaction of their nursing staff.

With the above in mind, the purpose of the present study was to explore and describe the job satisfaction of nursing staff working at the hospital. Specifically, the study addressed two research questions:

a) What is the general job satisfaction of hospital nursing staff?

b) Which intrinsic and extrinsic job factors contribute to the job satisfaction and dissatisfaction of hospital nursing staff?

Requests for copies should be addressed to: C Pietersen, charlottep@ul.ac.za

\section{Job satisfaction}

Job satisfaction is a multidimensional, enduring, important and much researched concept in the field of organizational behaviour (Bassett, 1994). The concept is an outgrowth of the human relations movement that began with the classic Hawthorne studies in the late 1920s. There is a lack of consensus as to what job satisfaction is (Hall, 1986), and how the job satisfaction of employees should be assessed. Buss (1988), for example, described job satisfaction as an employee's perception that his or her job allows the fulfillment of important values and needs. In this regard, according to Siegel and Lane (1982), motivational theories, such as equity theory, Maslow's need-hierarchy theory, and Herzberg's two-factor theory, all have substantial implications for understanding job satisfaction. Herzberg's theory is especially important as it distinguished between general types of work motivations, namely, intrinsic motivators and extrinsic motivators. These two groups of motivators were associated with job satisfaction and dissatisfaction, respectively (Buitendach \& De Witte, 2005; Herzberg, Mausner, \& Snyderman, 1959; Lu, 1999). Locke (1976, p. 1302) listed the common aspects of job satisfaction as work, pay, promotions, recognition, benefits, working conditions, supervision, co-workers, company, and management. Subsequent research indicated that these different aspects could be split according to Herzberg's two dimensions (Spector, 1997; Hirschfeld, 2000). Intrinsic satisfaction refers to job tasks and job content (such as variety, autonomy, skill utilization, self-fulfilment and self-growth), and extrinsic motivation refers to other factors such as pay, co-workers, and work conditions (Buitendach \& De Witte, 2005). Herzberg (1959) also made a distinction between satisfiers and dissatisfiers. If factors such as working conditions and supervisors are good, they are perceived as satisfiers, and vice versa. However, they are not perceived as motivators. Motivators include such things as opportunity for advancement and promotion, greater responsibility, opportunity for growth, and interesting work.

Different models for understanding and explaining job satisfaction were also developed. Lawler's (1973) model of facet satisfaction, for example, is closely related to equity theory. According to his model, employees are satisfied with a particular facet of their job (e.g. co-workers, supervisors, pay) when the amount of the facet they perceive that they should receive for 
performing their work at least equals the amount they actually receive. Locke's (1969) discrepancy theory, on the other hand, explains job satisfaction in terms of needs. It focuses on satisfaction and dissatisfaction with a job, and states that satisfaction, or dissatisfaction, with some aspect of a job depends on the perceived congruence or discrepancy between desires (needs) and outcomes (what is received), and the importance of what is wanted. Overall job satisfaction is the sum of each of the aspects of the job multiplied by the importance of the aspect for a person.

However, in recent year, managers and industrial/organizational psychologists tend to define satisfaction as a job attitude, along with other attitudinal concepts, such as morale, job involvement, and organizational commitment. Spector (1997), for example, refined job satisfaction as an attitudinal variable that measures how a person feels about his or her job in general, and also how he or she feels about different facets of the job. In their definitions Lofquist and Davies (1996), and Price (2001) focused on this affective component of attitudes. They described job satisfaction as the affective orientation that an employee has towards his or her work. In the words of Siegel and Lane (1982, p. 291) job satisfaction “... occurs when an individual subjectively appraises his/her current job situation and has a positive or pleasurable emotional response". Another theory that approaches job satisfaction from an affective point of view is Landy's (1978) opponent-process theory. This theory emphasises emotional equilibrium and regards job satisfaction and dissatisfaction as emotional states. Whereas job satisfaction pertains to positive feelings that individuals have relative to their jobs, job dissatisfaction indicates negative feelings that individuals have regarding their jobs or facets of their jobs (Hirschfeld, 2000; Spector, 1997).

\section{Measuring job satisfaction}

Presently, many organizations recognize the need to monitor the satisfaction levels of their employees (Terpstra \& Honoree, 2004), because employee dissatisfaction could be very costly and disruptive to organizational effectiveness. What's more, the concept is associated with other key organizational variables. In this regard, research findings indicated that job satisfaction correlates with, for example, employee motivation and performance (Judge, Bono, Thoresen, \& Patton, 2001; Ostroff, 1992), absenteeism (Hackett \& Guion, 1985), organizational citizenship behavior (Organ \& Ryan, 1995), and turnover (Griffeth, Hom, \& Gaertner, 2000).

One of the most popular ways to collect job attitudinal data is the use of job satisfaction questionnaires. Researchers who used job satisfaction questionnaires tended to employ two opposing approaches to the measurement of job satisfaction, namely, the use of a single global rating (Nagy, 2002), and using a summation score, made up of a number of job facets (Oshagbemi, 1999). The global rating method amounts to nothing more than asking individuals to respond to one question, such as "All things considered, how satisfied are you with your job?'” The other approach, a summation of job facets, is more sophisticated. It identifies key elements in a job and asks for the employee's feelings about each. Assessment instruments based on the latter approach normally cover a number of job-related factors such as supervision, coworkers, pay and benefits, promotional opportunities, working conditions, workload, and the organization (Douglas, Meleis, Eribs \& Kim, 1996; Fako, 2000; O' Driscoll \& Beerh, 1994; Siegel $\&$ Lane, 1982). The exact number of factors varies considerably from study to study, but research findings consistently support the multidimensional nature of job satisfaction (Koustelios \& Bagiatis, 1997).

There is also a growing awareness that it is vital to examine the job satisfaction of nursing staff (Dolan, 2003). Some of the reasons why it is so important to study the job satisfaction of nursing staff are: a) Research findings showed that the job satisfaction of employees in general (Greengard, 1983), and more specifically nursing staff (Gunner-Vaughn, 2003), is on the decline worldwide.

b) Critical nursing staff shortages are on the increase worldwide (Moyle, Skinner, Rowe \& Gork, 2003). There are many reasons for these nursing shortages (Miracle \& Miracle, 2004). Job related factors such as low pay, abuse by demanding patients, and lack of appreciation from doctors, work pressure, work environment-related factors, and lack of opportunities for advancement (Dolan, 2003; Smetherham, 2003; Venter, 2003), are some of the most important reasons leading to nursing skills losses. Emigration also contributes to nursing staff losses in South Africa (Venter, 2003).

c) Job satisfaction impacts on patient care (Cavanagh, 1992). Nursing staff with low job satisfaction levels may find it difficult to provide quality patient care, and to create a friendly and supportive atmosphere within the health care setting. Nurses with low levels of job satisfaction may also avoid work responsibilities, through absenteeism, and by taking shortcuts in the performance of their duties (Fako, 2000).

Different researchers found that different combinations of jobrelated factors were linked to the job satisfaction of nurses in hospitals. Table 1 provides examples of the findings of five studies on the job satisfaction on nurses working in hospitals in different countries.

A large body of job satisfaction research has accumulated either utilizing or attempting to validate well-known measures, such as the Minnesota Satisfaction Questionnaire (MSQ) (Buitendach \& De Witte, 2005; Weiss, Dawis, England, \& Lofquist, 1967), the Job Description Inventory (JDI) (Smith, Kendall \& Hulin, 1969), and the Job Diagnostic Survey (JDS) by Hackman and Oldham (1975).

In Greece the Employee Satisfaction Inventory (ESI) has been used extensively to assess the job satisfaction of different groups of employees (Koustelios \& Bagiatis, 1997; Koustelios, Kellis \& Bagiatis, 1999; Togia; Koustelios \& Tsigilis, 2004; Tsigilis, Koustelios \& Togia, 2004). Koustelios and Bagiatis (1997) originally developed and validated the ESI by using a sample of 212 public and private sector employees in their study. They used exploratory factor-analysis to extract the following six factors (with eigenvalues greater than 1.00): Working Conditions (five items), Immediate Supervisor (four items), Pay (four items), the Job Itself (four items), the Organization as a Whole (four items), and Promotion (three items). Each individual item was correlated with the factor concerned at the .50 level or above, and only items with a communality of greater than .50 were selected. The six factors that emerged accounted for $64.9 \%$ of the variance and, as such, their findings provide support for the construct validity of the instrument.

With regard to the reliability of the scales, examination of the Cronbach alpha coefficients showed that scores on the ESI subscales were reliable: Working Conditions (Alpha $=0,80$ ), Supervisor (Alpha $=0,82)$, Pay (Alpha $=0,79)$, Job Itself (Alpha $=$ 0,77 ), Organization as a Whole (Alpha $=0,76$ ), and Promotion (Alpha $=0,62)$. Koustelios and Bagiatis adopted an alpha coefficient of 0,60 as an acceptable criterion for the internal consistency of scores.

Custom-made questionnaires are often used to study job satisfaction of hospital staff. In general, custom-made inventories to examine the job satisfaction of nurses seem to be constructed with practical purposes in mind (Traynor \& Wade, 1993), instead of focussing on the theoretical and methodological adequacy of the instruments. Boumans and Landeweerd (1999), for example developed their own questionnaire to measure the job satisfaction of a group of hospital nurses in the Netherlands. Nearer to home, Fako 
TABLE 1

STUDIES ON JOB SATISFACTION OF HOSPITAL NURSES

\begin{tabular}{|c|c|c|c|c|c|}
\hline Factor & $\begin{array}{c}\text { McNeese-Smith (1999) } \\
\text { USA } \\
\text { Hospital nurses }\end{array}$ & $\begin{array}{l}\text { Fung-kam (1998) } \\
\text { Hong Kong } \\
\text { Hospital nurses }\end{array}$ & $\begin{array}{c}\text { Moyle et al. (2003) } \\
\text { Australia } \\
\text { Nurses, Nursing assistants }\end{array}$ & $\begin{array}{l}\text { Chu, Hus, Price \& } \\
\text { Lee (2003) } \\
\text { Taiwan } \\
\text { Hospital nurses }\end{array}$ & $\begin{array}{c}\text { Seo, Ko \& Price (2004) } \\
\text { Korea } \\
\text { Hospital nurses }\end{array}$ \\
\hline Patient care & $\mathrm{X}$ & & & & \\
\hline Environment & $\mathrm{X}$ & & & & \\
\hline Workload & $\mathrm{X}$ & & & & $\mathrm{X}$ \\
\hline Co-workers & $\mathrm{X}$ & & & $\mathrm{X}$ & $\mathrm{X}$ \\
\hline Salary and benefits & $\mathrm{X}$ & $\mathrm{X}$ & & & \\
\hline Professionalism & $\mathrm{X}$ & $\mathrm{X}$ & & & \\
\hline Cultural background & $\mathrm{X}$ & & & & \\
\hline Career stage & $\mathrm{X}$ & & & & \\
\hline Autonomy & & $\mathrm{X}$ & & & \\
\hline Workplace flexibility & & & $\mathrm{X}$ & & \\
\hline Residents & & & $\mathrm{X}$ & & \\
\hline Working in a team & & & $\mathrm{X}$ & & \\
\hline Dedication to service & & & $\mathrm{X}$ & & \\
\hline Training & & & $\mathrm{X}$ & & \\
\hline Role expectations & & & $\mathrm{X}$ & $\mathrm{X}$ & \\
\hline Laborious tasks & & & $X$ & & \\
\hline Staffing levels & & & $\mathrm{X}$ & & \\
\hline Overtime & & & $\mathrm{X}$ & & \\
\hline Affectivity & & & & $\mathrm{X}$ & \\
\hline Supervisor & & & & $\mathrm{X}$ & $\mathrm{X}$ \\
\hline Routinization & & & & $\mathrm{X}$ & $\mathrm{X}$ \\
\hline Management & & & & & $\mathrm{X}$ \\
\hline Resources & & & & $\mathrm{X}$ & \\
\hline
\end{tabular}

(2000) developed a "home-grown" questionnaire to conduct a survey on a national sample of nurses in Botswana. His questionnaire was used to identify key elements related to the job satisfaction of the nurses. The results of his study indicated that the nurses in the sample were, generally, not satisfied with their jobs. Unfortunately, only twelve of the thirty-one variables examined, were found to be associated with job satisfaction. Fako also failed to discuss the psychometric properties and the conceptual basis of his questionnaire. Arguably, a questionnaire with thirty-one variables is also too lengthy and time consuming for practical use.

To conclude, no generally accepted measure is currently in use to assess the job satisfaction, especially in the nursing profession. The lack of uniformity in the assessment of nurses' job satisfaction also makes it very difficult to compare results across different studies (Conrad, Conrad \& Parker, 1985).

\section{RESEARCH DESIGN}

Research approach

A cross-sectional, survey design was employed to collect job satisfaction data from the target population within relatively a short time frame. This type of design is commonly used to gather data from a representative cross-section of a population at a single point of time (Bailey, 1982; Fife-Shaw, 1997).

\section{Respondents}

Data was gathered at a government hospital located in the Capricorn District of the Limpopo Province, South Africa. The hospital has a nursing staff of 400 nurses (almost all of whom are females). A systematic random sample of $50 \%$ (200 subjects) of all nursing specialties (excluding higher-level managerial staff) was selected. In this project 109 questionnaires were returned. This yielded a response rate of $54,5 \%$.
The home language of the respondents is Northern-Sotho; their minimum scholastic qualification is Grade 12; and their language of education in secondary school, and during their nursing training, is English. None of the respondents indicated any difficulty with completing the questionnaire in English.

Table 2 provides the age distribution of sample.

TABLE 2

Age distribution OF THE SAMPLe

\begin{tabular}{ccc}
\hline Age & f & $\%$ \\
\hline $20-29$ & 16 & 15 \\
$30-39$ & 53 & 49 \\
$40-49$ & 35 & 32 \\
50 and over & 5 & 4 \\
\hline
\end{tabular}

Table 2 shows that majority of the participants (49\%) were in the age group 30-39, followed by the age group 40-49 (32\%), 15\% in age group $20-29$, and $4 \%$ above 50 years of age.

Table 3 provides a breakdown of the organizational position (ranks) of the respondents.

TABLE 3

RESPONDENTS BY BANK

\begin{tabular}{lcc}
\hline \multicolumn{1}{c}{ Rank } & f & $\%$ \\
\hline Registered Nurses & 72 & 66 \\
Staff Nurses & 25 & 23 \\
Nursing Assistants & 12 & 11 \\
\hline
\end{tabular}


It is clear from Table 3 that most of the respondents in the sample were Registered Nurses (66\%), followed by Staff Nurses (23\%), and Nursing Assistants (11\%).

Table 4 indicates (a) the number of years that respondents have been in their current positions, and (b) the number of years of employed as nurses.

TABLE 4

RESPONDENTS' NUMBER OF YEARS IN CURRENT RANK, AND IN THE NURSING PROFESSION

\begin{tabular}{lcccc}
\hline \multicolumn{1}{c}{ Years } & $\begin{array}{c}\mathbf{f} \\
\text { Current } \\
\text { rank }\end{array}$ & $\begin{array}{c}\% \\
\text { Current } \\
\text { rank }\end{array}$ & $\begin{array}{c}\mathbf{f} \\
\text { Nursing } \\
\text { profession }\end{array}$ & $\begin{array}{c}\% \\
\text { Nursing } \\
\text { profession }\end{array}$ \\
\hline Less than five years & 44 & 40 & 18 & 16 \\
6 to10 years & 44 & 40 & 23 & 21 \\
11 to 15 years & 13 & 12 & 38 & 35 \\
16 years and more & 8 & 8 & 30 & 28 \\
\hline
\end{tabular}

From an inspection of Table 4 it is evident that the majority of the participants has been working in their current ranks for less than five years (40\%), and six to ten years (40\%), respectively. It is also apparent from the table that the respondents were relatively evenly spread in terms of the number of years that they were employed as nurses.

\section{Measuring instrument}

In the present study job satisfaction was approached from an attitudinal point of view. The choice of a measuring instrument was based on the following criteria (Koustelios \& Bagiatis, 1997): (a) The instrument should be useful to examine a wide variety of employees in a variety of jobs. (b) The verbal content of the items in the instrument should at a level that it can be understood all employees (also by those who used English as a second language). (c) The instrument should be valid and reliable. (d) The instrument should yield separate scores for different facets of job satisfaction.

Most existing measures do not adequately meet all of the above criteria. Therefore, the decision was made to compile a short, practical instrument, the Job Satisfaction Questionnaire (JSQ), using a selection of items from the study reported by Koustelios and Bagiatis (1997).

The JSQ has its own instructions for completion, item sequencing, response scale format, and scoring key. The average time for completion of the instrument is about 5 minutes. The instrument contains three items for each of the job satisfaction factors (Working Conditions, Supervision, Pay, the Job Itself, Organization, and Promotion) identified by Koustelios and Bagiatis (1997). Each group of three items selected were the ones that showed the highest item-scale correlations with each of the factors in the Koustelios and Bagiatis study. Seven of the selected items are reverse scored and a six-point Likert-type response scale, varying from strongly disagree (value $=1$ ) to strongly agree (value $=6$ ), was used to measure the six factors. Three openended questions are also included in the questionnaire ("What are the things you like about your job"? "What are the things you dislike about your job"? "What do you think will make you satisfied with your job"?).

\section{Procedure}

Data was collected through the administration of the JSQ. Following approval to conduct the study, copies of the JSQ were distributed among nursing staff at the hospital. A cover letter explained the purpose of the study. Respondents were assured of the confidentiality of survey. They were given a week to complete the questionnaire, and completed questionnaires were returned via conveniently placed boxes at the respondents' workplace.

\section{Statistical analysis}

The data was entered into the SPSS 12.0 for Windows (SPSSSouth Africa). Descriptive statistics (percentages) were used to report the job satisfaction of respondents. An overall job satisfaction score was computed for the sample. Percentages of agreement/disagreement with different aspects of job satisfaction were also calculated for each job satisfaction factor included in the questionnaire.

The measurement characteristics of the JSQ were explored to check the reliability and validity of the instrument. Reliability figures (Cronbach Alphas), and results of a Principal Components Analysis (PCA), with Varimax rotation, were obtained to provide data on the construct validity of the instrument. A second round of factor analysis (PCA) was conducted treating job satisfaction scales as variables, in a further exploration of the data.

\section{RESULTS}

\section{Measurement properties of the JSQ}

Due to a lack of space, only a brief overview of the measurement properties of the JSQ is provided to support the reliability and validity of results and conclusions of the study. The results showed that obtained reliability figures (Alphas) range from .64 to 0,76 . These findings provide support for the internal consistency of the sub-scales. All in all, $60 \%$ of the total variance (eigenvalues $>1,00$ ) was explained by the principal components solution in the present study. This result provides evidence of construct validity of the instrument. Despite the fact that the JSQ contains fewer items than the ESI, these findings, to a large extent, mirror the finding of the study by Koustelios and Bagiatis (1997). It can be concluded that the above findings provide support for the reliability and validity of results and conclusions of the present study.

A factor analysis of the JSQ also revealed two principal components accounting for $63,5 \%$ of total variance (eigenvalues $>1$ ). The results provide tentative support for distinguishing between Herzberg's extrinsic and intrinsic sources of job satisfaction. One component explained intrinsic work factors (mainly the Job Itself factor, but also the Promotion factor), while the other four components accounted for extrinsic work factors, namely, satisfaction with: Working Conditions, Supervisor, Pay, and the Organization.

\section{Job satisfaction}

Table 5 presents respondent level satisfaction and dissatisfaction (percentages) with the six factors measured in the study. The six factors were grouped into intrinsic and extrinsic job factors, and the average satisfaction/dissatisfaction on each group (intrinsic and extrinsic) was calculated. Average percentages for each of the factors, as well as the percentage for each item in the questionnaire are listed. All the average percentages are in bold. The general job satisfaction and dissatisfaction levels of the group of respondents are also given.

The findings reported in Table 5 show that there was no clear difference between general levels of job satisfaction and dissatisfaction, although more respondents were dissatisfied (56\%) than those who were satisfied (44\%). Respondents were also somewhat more dissatisfied with extrinsic work factors $(58 \%)$ than with intrinsic factors $(52,5 \%)$.

On the intrinsic factors, specifically, they were more satisfied with the Job Itself (52\%) than with Promotion (43\%). With regard to the Job Itself, most of the respondents (63\%) indicated that their jobs were worthwhile. Table 6 also shows that at least 
some of the respondents (53\%) found it satisfying to take care of their patients. However, the results in Table 5 indicated that 57\% felt that their jobs were routinized and this impacted negatively on their intrinsic job satisfaction.

TABLE 5

SATISFACTION/DISSATISFACTION WITH JOB SATISFACTION FACTORS

\begin{tabular}{lcc}
\hline Factor & \% satisfied & \% dissatisfied \\
\hline Intrinsic factors & 47,5 & 52,5 \\
$\quad$ Job itself & 52 & 48 \\
Routine & 43 & 57 \\
Worthwhile & 63 & 37 \\
Fulfilling & 51 & 49 \\
$\quad$ Promotion & 43 & 57 \\
Experience & 53 & 47 \\
Prospects & 32 & 68 \\
Likelihood & 44 & 56 \\
Extrinsic factors & 42 & 58 \\
Working Conditions & 43 & 57 \\
Pleasant & 39 & 61 \\
Best ever & 31 & 69 \\
Impact on health & 59 & 41 \\
Supervisor & 37 & 63 \\
Understand problems & 45 & 55 \\
Support & 35 & 65 \\
Irritation with & 32 & 68 \\
Pay & 39 & 61 \\
Insecure with & 73 & 27 \\
Paid for work done & 21 & 79 \\
Less than deserved & 23 & 77 \\
Organisation & 49 & 51 \\
Favouritism & 73 & 27 \\
Support & 33 & 67 \\
Best worked for & 42 & 58 \\
General job satisfaction level & 44 & 56 \\
\hline & & \\
\hline & & \\
\hline
\end{tabular}

Table 6 represents a summary of the respondents' views on: (a) Things that they like about their jobs. (b) Things that they dislike about their jobs. (c) Things that will make them more satisfied with their jobs

TABLE 6

RESPONDENTS' COMMENTS

\begin{tabular}{ll}
\hline Factor & $\%$ \\
\hline Likes & \\
Patient care & 53 \\
Cooperation with staff & 15 \\
Seeking new experiences & 19 \\
Nothing & 13 \\
Dislikes & \\
Work not in job description & 38 \\
Overwork & 19 \\
Underpaid & 25 \\
Favouritism & 18 \\
Improvements & \\
Salary increase & 60 \\
Working conditions & 15 \\
Patient care & 11 \\
Increase staff & 14 \\
\hline
\end{tabular}

The findings in Table 5 indicate that the respondents were mostly dissatisfied with all four extrinsic factors measure in the study. The results indicated that:

a) $57 \%$ of the respondents (irrespective of age and rank) were not satisfied with their working conditions. A more detailed analysis showed that the majority felt that the working were unpleasant (61\%). They also indicated the working conditions at the hospital were the worst that they have experienced so far in their working lives (69\%). However, most of them (59\%) indicated that the working conditions were not bad for their health.

b) Overall, most of the nursing staff (63\%) was dissatisfied with their supervisors. More specifically, most of the respondents (65\%) indicated that their supervisors did not support them. Also, 68\% indicated that their supervisors irritated them. However, there was not much difference between respondents who indicated that their supervisors did not understand their problems (55\%), and those who felt that supervisors did understand (45\%).

c) The majority of respondents were unhappy with Pay (61\%). They felt that they did not get paid enough for what they did (79\%) or that remuneration was less than what they deserved (77\%). (The results in Table 6 showed that $60 \%$ felt that the organization should increase their pay). However, most of them (73\%) did not fell insecure and felt that the organization had enough resources to pay their salaries.

d) Only $49 \%$ of the respondents were satisfied with their organization. A more detailed analysis showed that a large majority (67\%) indicated that the organization did not support them. Most of them (58\%) also believed that the hospital was not a good place to work. However, a large majority (73\%) indicated that there was no favouritism present in the organization.

\section{DISCUSSION}

It is evident from the literature that low levels of job satisfaction are associated with high turnover rates. The findings of the present study show that the nursing staff at the hospital were, in general, not clearly satisfied or dissatisfied. As such, it would be difficult to use their general level of job satisfaction to predict the turnover rate at the hospital. However, some specific factors could positively influence decisions of nursing staff to stay at the hospital. These factors are:

a) Most of the respondents indicated that their jobs were worthwhile.

b) More than half of the respondents indicated that they found it satisfying to take care of their patients.

c) Most of the respondents indicated there was financial stability in the organization. Financial stability is one of the most appealing aspects of a nurse's job (Koebel, Fuller \& Misener, 1991).

On the other hand, the findings also show that extrinsic and intrinsic job factors that could negatively impact on the turnover rate of nursing staff at the hospital are present in the situation. The literature shows that extrinsic factors, such as working conditions, supervision, management styles, and salary negatively affect the job satisfaction of employees. Most of the respondents in the present study indicated that they were dissatisfied with their interactions with their supervisors. They were also clearly dissatisfied with their remuneration and unhappy with the working conditions in the hospital. Lastly, they indicated that the organizational climate was not conducive to generate high levels of job satisfaction. These extrinsic factors will continue to contribute to job dissatisfaction unless management actively intervenes to address these issues.

The literature also shows that routinization, and the resulting a lack of opportunities to be creative, has a great impact on the intrinsic job satisfaction of nurses in hospitals. The findings of the present study also indicated that routinization impacted 
negatively on the job satisfaction of the respondents. However, much of a nurse's job inherently contains routine activities. As such, it would probably be difficult, but not impossible, to provide opportunities for creativity at the target hospital.

Job satisfaction literature also provides evidence that hospital nurses are, in general, satisfied with opportunities for promotion (another intrinsic job factor). However, the respondents in the present study were mostly dissatisfied with promotion in general, and/or their chances for promotion in particular. This is another issue that the hospital management needs to focus on.

To conclude, nursing shortages will continue to increase in future. An important reason for this is that staff retention is associated with job satisfaction. It is therefore recommended that hospital's administrators should take proactive steps to retain their staff. The job satisfaction of nursing staff is on the decline worldwide. This means that proactive interventions are needed to ensure that the job satisfaction of nursing staff at the target hospital, or at any other hospital in a similar situation, does not decline.

The following proactive interventions to decrease the influence of intrinsic job factors could be taken. (a) Hospital managers could enhance the commitment of, and empower nursing staff, by obtaining their input on possible actions to be taken to create opportunities to be more creative in their jobs and to counteract the impact of routinization on job satisfaction. (b) Hospital administrators should also create opportunities for promotion in situations where staff advancement is identified as a problem. Only a small number of respondents in the present study indicated that they would be more satisfied if the staff complement of the hospital was increased. This means that the management of the hospital should attend to staff promotions to increase the intrinsic job satisfaction of their nursing staff, instead of recruiting staff from outside sources.

In addition to focussing on intrinsic job factors, hospital administrators also need to take active steps lessen the negative impact of extrinsic job factors on the job satisfaction of nursing staff. Hospital administrators would be advised: (a) to take active steps to 'make the hospital a more pleasant place to work at', (b) to develop the interpersonal skills of supervisor, (c) to implement ways and means to actively support nursing staff and to develop a caring organizational climate, and (d) to amend the pay packages of nursing staff, it at all possible.

Finally, to promote excellence in nursing care in hospitals in South Africa, and to address the critical shortage of nurses in the country, research should be conducted on other research and gender populations in the nursing professions. Further research could, for example, be conducted on nursing staff in different health care settings, in different hospitals, and in other parts of the country.

Information on the job satisfaction of nursing staff must be disseminated to interested parties throughout the field. Such information is of critical importance to health care managers who need to address the critical nursing staff shortages in South Africa. Information on levels of job satisfaction, and intrinsic and extrinsic job factors are also essential for health care managers who are committed to the happiness and satisfaction of their employees, and to quality patient care.

\section{REFERENCES}

Bailey, K. D. (1982). Methods of social research. (2nd Ed). London: Collier Macmillan.

Bassett, G. (1994). The case against job satisfaction. Business Horizons, 37 (3), 61-69.

Boumans, N. P. G. \& Landeweerd, J. A. (1999). Nurses' well-being in a primary nursing care setting in the Netherlands. Scandinavian Journal of Caring Sciences, 13 (2), 116-122.
Buitendach, J. H. \& De Witte, D. (2005). Job insecurity, extrinsic and intrinsic job satisfaction and affective organizational commitment maintenance workers in a parastatal. South African Journal of Business Management, 36 (2), 27-39.

Buss, J. (1988). Job satisfaction, powerlessness and locus of control. Western Journal of Nursing Research, 10 (6), 718-731.

Cavanagh, S.J. (1992). Job satisfaction of nursing staff working in hospitals. Journal of Advanced Nursing, 17, 704-711.

Conrad K. M., Conrad, K. J. \& Parker, J. E. (1985). Job satisfaction among occupational health nurses. Journal of Community Health Nursing, 2 (3), 161-173.

Chu, C. I., Hus, H. M. Price, J. L. \& Lee, J. Y. (2003). Job satisfaction of hospital nurses: An empirical test of a causal model in Taiwan. International Nursing Review, 50, 176-182.

Dolan, L. A. (2003). Management style and staff nurse satisfaction. Dimensions of Critical Care Nursing, 22 (2), $97-$ 98 .

Douglas, M. K., Meleis, A. I., Eribs, C. \& Kim, S. (1996). The work of auxillary nurses in Mexico: Stressors, satisfiers and coping strategies. International Journal of Nursing studies, 33 (5), 495505.

Evans, M. (2005). On the job. Modern healthcare, 35 (14), 14-15.

Fako, T. (2000). Job satisfaction among nurses in Botswana. Society in Transition, 31 (1), 10-21.

Fife-Schaw. (1997). Surveys and sampling issues. In Breakwell, G. M., Hammond, S. \& Fife-Schaw, C. (Eds). Research methods in psychology. London: Sage.

Fung-kam, L. (1998). Job satisfaction and autonomy of Hong Kong registered nurses. Journal of Advanced Nursing, 27 (2). Retrieved from EBSCOHOST: Academic Search Premier, 157.

Greengard, S. (2004). The five-alarm job. Workforce Management, 83 (2), 43-46.

Griffeth, R.W., Hom, P.W. \& Gaertner, S. (2000). A meta-analysis of antecedents and correlates of employee turnover: Update, moderator tests, and research implications for the next millennium. Journal of Management, 26 (3), 463-479.

Gunner-Vaugh, R. M. (2003). Simple steps to satisfaction. Nursing Management, 34 (5), 20-22.

Hackett, R.D. \& Guion, R.M. (1985). A reevaluation of the absenteeism-job satisfaction relationship. Organizational Behavior and Human Decision Processes, 35 (3), 340-381.

Hackman, J. \& Oldham, G. (1975). Development of the job diagnostic survey. Journal of Applied Psychology, 60, 159-170.

Hall, C. (1986). Measuring job satisfaction. Nursing Times, 82 (5), 43-46.

Herzberg, P. (1959). The Motivation to Work. New York: John Wiley.

Herzberg, F., Mausner, B. \& Snyderman, B. (1959). The Motivation to Work. New York: John Wiley.

Hirschfeld, R.R. (2000). Validity studies. Does revising the intrinsic and extrinsic subscales of the Minnesota Satisfaction Questionnaire Short Form make a difference? Educational Psychological Measurement, 60, 255-270.

Igbaria, M., Meredith, G. \& Smith, D.C. (1994). Predictors of intention of IS professionals to stay with the organization in South Africa. Information and Management, 26 (5), 245-256.

Judge, T., Bono, J., Thoresen, C. \& Patton, G. (2001). The job satisfaction-job performance relationship: A qualitative and quantitative review. Psychological Bulletin, 127, 376-407.

Koebel, P. W., Fuller, S. C. \& Misener, T R. (1991). Job satisfaction of nurse practitioners: An analysis using Herzberg's theory. Nurse Practitioner, 16 (4), 43-48.

Koustelios, A, D. \& Bagiatis, K. (1997). The employee satisfaction inventory (ESI): Development of a scale to measure satisfaction of Greek employees. Educational and Psychological Measurement, 57 (3), 469-477.

Koustelios, A. D, Kellis, S. \& Bagiatis, K. (1999). The relationship between burnout and job satisfaction among physical education teachers: a multivariate approach. European Journal for Sports Management, 6 (1), 31-39.

Lacey, L. M. (2003). Called into question: What nurses want. Nursing Management, 34 (2), 15-16. 
Landy, F. J. (1978). An opponent process theory of job satisfaction. Journal of Applied Psychology, 63, 533-547.

Lawler, E. E. (1973). Motivation and work organizations. Monterey, California: Brooks/Cole.

Locke, E.A. (1976). The nature causes and causes of job satisfaction. In Dunnette, M.C. (Ed.). Handbook of industrial and organisational psychology. Chicago, IL: Rand McNally.

Locke, E. A. (1969). What is job satisfaction? Organizational Behavior and Human Resources Management, 4, 309-336.

Lofquist, L. H. \& Davies, R. v. (1969). Adjustment to work: A psychological view of man's problems in a work-orientated society. New York: Applton-Century-Crofts.

Lu, L. (1999). Work motivation, job stress and employees' wellbeing. Journal of Applied Management Studies, 8 (1), 161-172.

McNeese-Smith, D. K. (1999). A content analysis of staff nurse descriptions of job satisfaction and dissatisfaction. Journal of Advanced Nursing, 29 (6). Retrieved from EBSCOHOST: Academic Search Premier, 139.

Miracle, V. \& Miracle, J. (2004). The nursing shortage. Critical Nursing Care, 23 (5), 236-237.

Moyle, W, Skinner, J, Rowe, G. \& Gork, C. (2003). Views of job satisfaction and dissatisfaction in Australian long-term care. Journal of Clinical Nursing, 12 (2). Retrieved from EBSCOHOST: Academic Search Premier, 64.

Murrow, J. \& Nowak, P. (2005). What nurses want. Health Services, 25 (1), 25-28.

Nagy, M. S. (2002). Using a single-item approach to measure facet job satisfaction. Journal of Occupational and Organizational Psychology, 75 (1), 77-87.

O'Driscoll, M. P. \& Beerh, T. A. (1994). Supervisor behaviors, role stressors and uncertainty as predictors of outcomes for subordinates. Journal of organizational Behavior, 15 (2), 141-155.

Organ, D.W. \& Ryan, K. (1995). A meta-analytic review of attitudinal and dispositional predictors of organizational citizenship behavior. Personnel Psychology, 48, 775-803.

Oshagbemi, T. (1999). Overall job satisfaction: how good are single versus multiple-item measures? Journal of Managerial Psychology, 14 (5/6), 388-404.

Ostroff, C. (1992). The relationship between satisfaction, attitudes, and performance: An organizational level analysis. Journal of Applied Psychology, 77, 963-974.
Price, J. L. (2001). Reflections on the determinants of voluntary turnover. International Journal of Manpower, 22 (7), 600-624.

Seo, Y, Ko, J. \& Price, J. L. (2004). The determinants of job satisfaction among hospital nurses: A model estimation in Korea. International Journal of Nursing Studies, 41 (4), 437-447.

Siegel, L. \& Lane, I. M. (1982). Personnel and organizational psychology. Georgetown, Ontario: Irwin-Dorsey.

Smetherham, J. (2003). SA in short of 31000 nurses, says minister. Cape Times, Online edition 8 July 2005. Retrieved from the World Wide Web, July 6, 2005:http://www. capetimes.co.za/index.php?fArticleld $=209416$.

Smith, P., Kendall, L. \& Hulin, C. (1969). The measurement of satisfaction in work and retirement. Chicago: Rand McNally.

Spector, P. E. (1997). Job satisfaction: Applications, assessment, causes, and consequences. Thousand Oaks, CA: Sage.

SPSS 12.0 for Windows. SPSS-SA. Cape Town.

Terpstra, D. E. \& Honoree, A. L. (2004). Job satisfaction and pay satisfaction levels of university faculty by discipline type and by geographical region. Education, 124 (3), 528-539.

Traynor, M. \& Wade, B. (1993). The development of a measure of job satisfaction for use in monitoring the morale of community nurses in four trusts. Journal of Advanced Nursing, 18, 127-139.

Togia, A., Koustelios, A. \& Tsigilis, N. (2004). Job satisfaction among Greek academic librarians. Library and Information Science Research, 26 (3), 373-384.

Tsigilis, N., Koustelios, A. \& Togia, A. (2004). Multivariate relationship and discriminant validity between job satisfaction and burnout. Journal of Managerial Psychology, 19 (7), 666-676.

Venter, B. (2003). Crisis as SA steadily loses qualified nursing. The Star, 5 July 2005. (Online Ed.). Retrieved from the World Wide Web, July 6, 2005: http://www.thestar.co.za/index. php? fSectionld $=129 \&$ Atricleld $=2373406$.

Weiss, D., Dawis, R., England, G. \& Lofquist, L. I. (1967). Manual for the Minnesota Satisfaction Questionnaire. Minneapolis: Industrial Relations Centre, University of Minnesota, Work Adjustment Project. 